\title{
平板マイクロレンズの高精度芯合せ制御*
}

\author{
岡田養二*1, 上田雄 悟*2, 植田嘉昭*3 \\ 中 村 雅 之*3, 浜中 賢二郎*4
}

\section{High-Precision Alignment Servo of Planar Microlens Array}

\author{
Yohji OKADA, Yugo UEDA, Yoshiaki UEDA, \\ Masayuki NAKAMURA and Kenjiro HAMANAKA
}

\begin{abstract}
Optical fiber is commonly used for long-distance communication. For short-distances, parallel communication should be developed, but this requires a multiport connection. A planar microlens array (PML) has been developed and is considered adequate for such an application. However, alignment of the PML is very difficult and is an obstacle to wide application. This paper introduces a new technique for aligning two PMLs using many-to-one optics. Instead of aligning each lens, optical focuses of PML are projected to one image by using many-to-one optics which consist of optical neurons. This image is input to a microcomputer, and a vision servo is developed. Two vision algorithms are tested : one calculates the alignment error from the digitized image, while the other uses a layered neural network. The alignment capability is tested and discussed.
\end{abstract}

Key Words: Optical Servo, Neural Network, Positioning, Accurate alignment, Data Communication, Vision System

\section{1 はじめに}

長距礁の通信手段として、光ファイバーが広く使われる ようになってきた $[1]$ 。一方、短距離の並列光通信や画像処 理、光コンピュータに、平板マイクロレンス（PML）の 使用が検討され、広い応用が期待されている[2]。しかし 直径数十〜数百 $\mu \mathrm{m}$ のレンズを、精度良く芯合わせする技 術が礁立されておらず、充分に応用されてはいない。 本詥文では、イオン交換法を用いた分布屈折率平板マイク ロレンスについて、その特性と応用を紹介すると共に[2][3]、 PMLの特性を利用した Many-to-One 光学系を使い [3] 、 2 枚のPMLの高精度芯合わせサーボへ応用した。これは、 今後拡大するであろう PMLの応用に対して、組込のため の重要な基磷技術である。この光学系で作られる画像を、 C C Dカメラによってコンピュータに取込み、全自䖝芯合 わせの基碳実㧱を行った。画像処理のアルゴリズムとして は、二值化画像から芯ずれを検出する方法と、階層型ニュー ラルネットワークの二種類を武みた [4][5]。

* 原稿受付 平成 4 年 3 月 13 日.

*1 正員, 茨城大学工学部 ( 316 日立市中成沢町 4-12-1).

*2 茨城大学工学部.

*3 学生員, 茨城大学大学院.



2 平板マイクロレンズ (PML) について

\section{1 平板マイクロレンスの㱔作とその特性}

平板マイクロレンスは、半学体工場で用いられるプレー ナ技術を応用して作られる [2]。具体的には、ガラス基板 に屈折率を高くするドーパントを選択的に搪散して、図 1 に示すようなレンズアレーを実現する。ドーパントを選択 的に搪散するためには、おらかじめ所定の 1 価の陽イオン を含ませたガラス基板を、マスク処理しておく。このマス クの中の小さな穴を介して、高温の溶解堛と接触させるこ とにより、ガラスの中の 1 值の陽イオンと、溶解垭の中の 他の 1 洒の隔イオンを交換するものである。イオン交換を 行うと、ガラスの密度変化が生ずると共に、置き玫わった

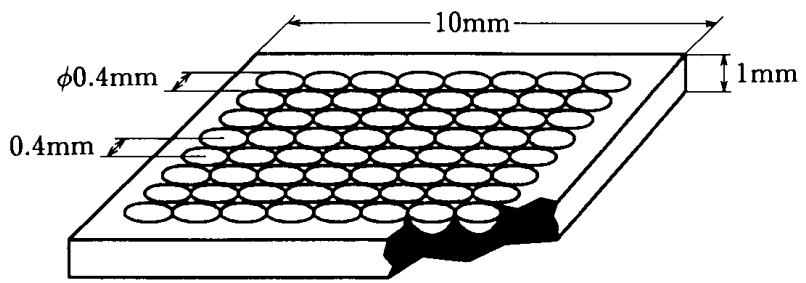

図 1 平板マイクロレンス 
イオンの電子分栖率が異なるため、ガラスの屈折率を舞化 させることができる。

このイオン拡散は、非常に強い湌度依存性を持つ。拡散

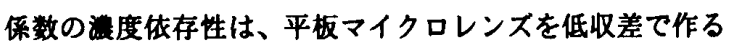
上て、檑めて重要な要因となっている。应散保数が湍度依 存性を持つことて、周匄部で急嶛な屈折率分布が得られ、 収差の小さく良好な平板マイクロレンズが作成できる [2]。 表 1 に本方式で製作できた平板マイクロレンズの特性と、 実検て使用するものを示す。平板マイクロレンスに、平行 光をあてたときの光軌跡のシミュレーションを、図 2 に示 す。レンズの直径は $200 \mu \mathrm{m}$ で、直径の $90 \%$ 以内の颃域で 小さな収差で光を集光している。

\section{2 応用例}

平板マイクロレンスは、マスクパターン通りに高精度の レンスアレーを作成できるので、光エレクトロニクスの分

表 1: 製作可能な平板マイクロレンスと使用したものの特性表 \begin{tabular}{|l||c||c|}
\hline & Manufacturable Lens & Tested Lens \\
\hline Baseplate Size & $\max 20 \times 20 \mathrm{~mm}$ & $10 \times 10 \mathrm{~mm}$ \\
Lens Pitch & $20 \mu \mathrm{m}-2 \mathrm{~mm}$ & $400 \mu \mathrm{m}$ \\
Lens Diameter & $\phi 20 \mu \mathrm{m}-1.2 \mathrm{~mm}$ & $\phi 400 \mu \mathrm{m}$ \\
Number of Lens & $\max 500 \times 500$ & $21 \times 21$ \\
Focus & $0.02-5 \mathrm{~mm}$ & $1 \mathrm{~mm}$ \\
\hline
\end{tabular}

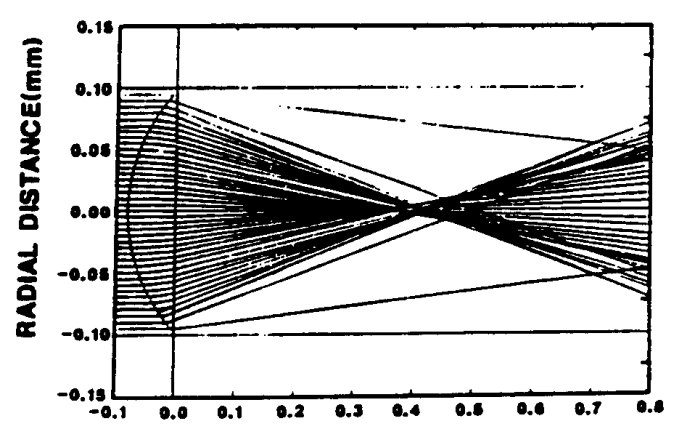

AXIAL DLSTANCE(mm)

図 2 平板マイクロレンズの光軌跡

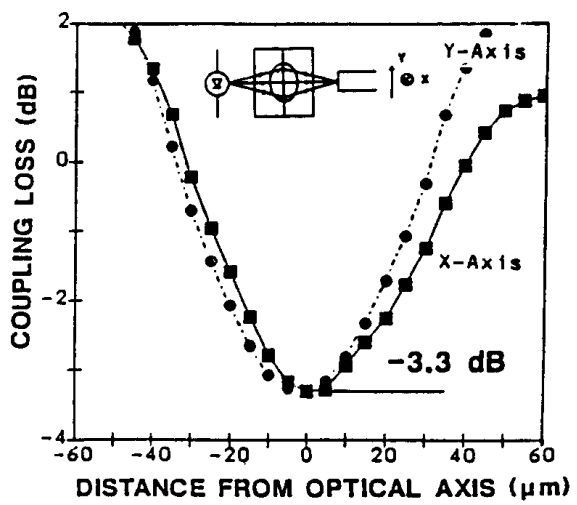

図 3 L E D と光ファイバー接続への応用
野て広い応用が可能である。実用化になった例として、做 晶シャッターアレイとの組み合わせがある。波晶シャッター は面の一部しか光を通さないのて、、マイクロレンスで光を そこに集め、通遇効率を改善する。これは、カラー液晶ティ スプレーの一部に採用されている。もう一つの例として、 L E Dをマルチモード光ファイバへ結合した場合の、結合 度の改軲を图 3 に示す。立檕はファイバを直接 L E D に結


レンスを使うことで $3.3 \mathrm{~dB}$ の改書を示している。

他の応用例としては、C C Dとの組み合わせ、光コンピ ュータへの応用などが考えられている [1][2]。

\section{Many-to-One (光ニューロン) 光学系}

以上述へてきたように、平板マイクロレンズは简単に精 度良く作れ、広い応用笛囲が考えられているが、芯合わせ が雷めて困花であるという久点を持つ。例えは图 3 のL E Dとファイバの結合には、2 枚の P M L を貼り合わせたも のを使用していろか、この貼り合わせを、影微篭の下で人 手で行うには数時閔を要し、しかも充分に满足いくものが 作られていない。

\section{1 実悇装置}

本研究では 2 枚のP M L の貼り合わせを取り上げ、画像 処理による全自動芯合わせを試みる。実畭装专の構成を、 図 4 に示す。 H e - N e レーザから出た光は、ビームエキ スパンダで平行光線に変えられ、2枚の P MLへ照射され ろ。PML 1 とPML 2 を通遇した光は、C C D カメラレ ンスによって受光部へ算かれ、ビテオ信号に変执されてコ ンピュータへ取り込まれる。コンピュータ内部で画像処理 した後に、PML 2 を支持しているステージを取功し、芯 合わせサーボを行う。

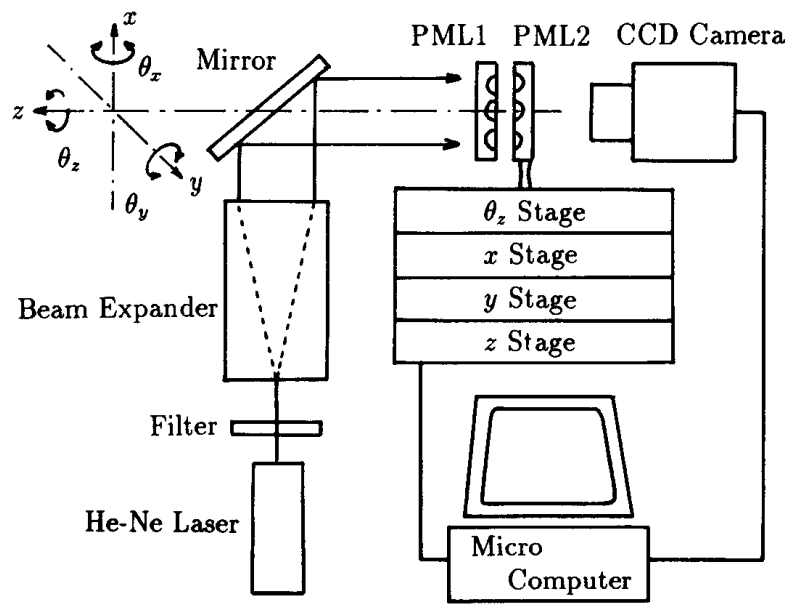

図 4 実臨装置の権成 
今回取り上げた P M L は、大きさ $10 \times 10 \mathrm{~mm}$ 、レンス ピッチ $400 \mu \mathrm{m}$ 、レンズ径 $\phi 400 \mu \mathrm{m}$ 、レンズ数 $21 \times 21$ 、焦 点距鷹 $1 \mathrm{~mm}$ のものである。貼り合わせを行うには、全て のレンズが $5 \mu \mathrm{m}$ 程度以内の芯合わせ精度を必要とする。

今までに、2 枚の PMLを接着できる距崔まで近つけて

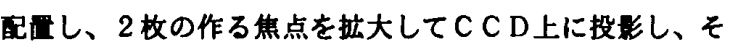
の焦点の合い方から芯合わせを試みた。しかし C C Dの分

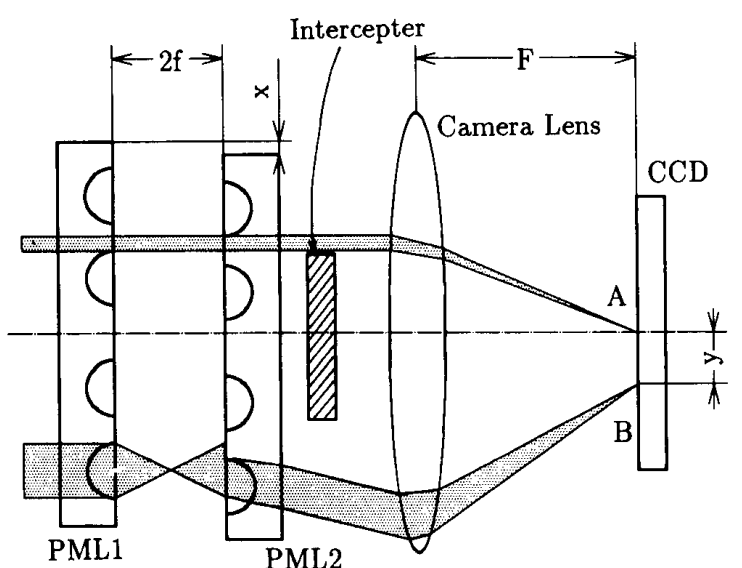

図 5 Many-to-One 光学系

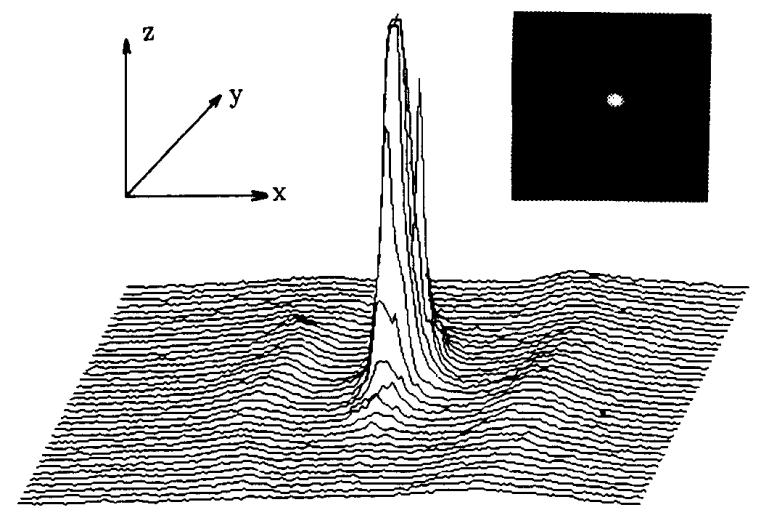

(a) 芯か合っている状腎

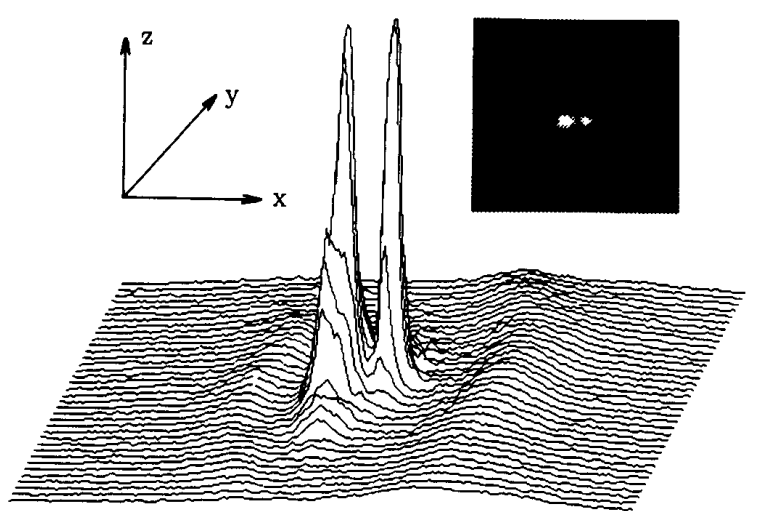

(b) $\delta \mathrm{x}=10 \mu \mathrm{m}$ ずれている状態
解能から、充分な性能は得られなかった。また 2 つのレン スが作る、光干涉モアレによる芯合わせも試みたが、画像 処理が困萑で成功しなかった。今回、Many-to-One 光学系 を使った光サーボを考え、精度良い芯合わせに応用する。

\subsection{Many-to-One 光学系の特性}

本方式は、PML 1 とPML 2 をその焦点距離の 2 倍倠 す必要がある。図 5 に、平行光を照射した系の概要を示す。 平行レーザ光はPM L 1 に入り、その焦点を 441 個作る。 第 2 のマイクロレンズ P M L 2 とC C Dカメラレンズが、 Many-to-One 光学系を作る [3]。即ち、P M L 2 は 441 個 の焦点像 (Many) を平行光に変える。これがC C Dカメラ レンズより一点 (One) に集められ、1 個の像 Bになる。 PML 1 とPML 2 の焦点のずれは、 $F / f$ 倍されてC C D 上に結像される $(\mathrm{F}, \mathrm{f}:$ カメラレンズおよび $\mathrm{P} \mathrm{ML}$ の焦点距 譙)。今回使用したレンズは、 $F=12.5 \mathrm{~mm}, f=1 \mathrm{~mm}$ で、 12.5 倍される。しかも P M Lを通らない点線のレーザ光は、 C C Dの中央に集光されるため、この点 Aを基淖として芯 合わせを行うことができる。441 個の焦点を 1 点に集める

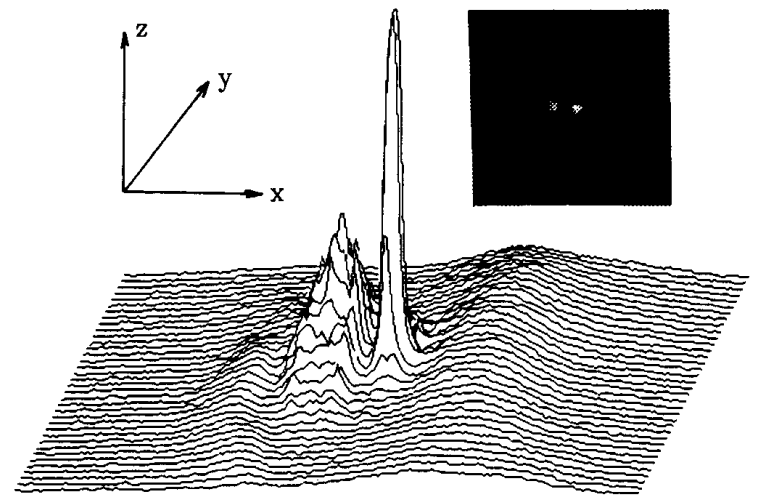

(c) $\delta \theta_{z}=0.05 \mathrm{deg}$ ずれ、かつ $\delta \mathrm{x}=10 \mu \mathrm{m}$ 移動 している (遮光板なし)

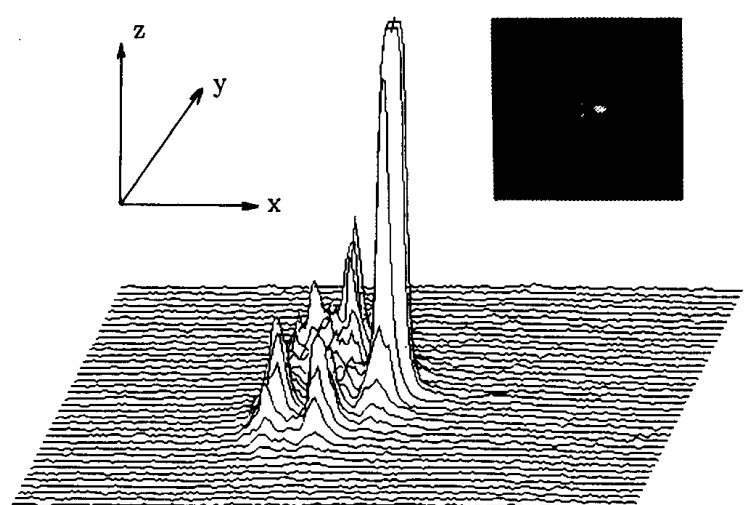

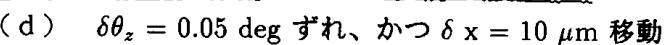

している（遮光板あり）

図 $6 \quad C$ C D 画像の 3 次元輝度表示 
と、焦点がぼけてしまう。P M L が精度良く作れるのであ れば、4 隅の数個のレンズの芯合わせを行えば良い。この 目的で遮光板を使う。

\section{3 芯合わせ実験結果}

ここでは、Many-to-One 光学系によって作られる、2つ の焦点を使って芯合わせが可能かどうかの判定を行った。

図 6 にC C D 上の焦点画像の例と、その光輝度の 3 次元 グラフィックを示す。(a) は最も芯の合ったと思われろ状貿 て、平行光によるスポットと、Many-to-One 光学系のスポッ トが一致している。（b）はそれよりる、 $\delta x=10 \mu m$ ずら したもので、x 方向にずれた 2 つのスポットが現れている。 y 方向にずれた場合は、Many-to-One スポットも y 方向に ずれ、方向を検出できる。(c) は回転方向を $\delta \theta_{z}=0.05 \mathrm{deg}$ 移動させ、かつ锤测し易いようにx方向にも $\delta x=10 \mu \mathrm{m}$ 動かしたものである。スポットが広がっている様子がわか る。これは回転によって、中心に近いレンズはずれが小さ いが、端のレンズはずれが大きいためである。遮光版を捕 入することにより、(d) のように4つに分かれたピークか 現れ、回転誤差を検出することができる。使用したカメラ では、 $1 \mu \mathrm{m}$ のずれがC C Dの 1 ビットずれに相当し、充分 な検出精度を持っていた。

\section{4 画像の 2 値化処理による自動芯合せ}

本実験で使用したコンピュータにはＣＣＤカメラが取り 付けられ、ビテオ信号に変換した画像を、テータとして取 り込むことができる。画像は、 $512 \times 512$ 素子で 256 階調 (8bit) の数値データとなる。最初に画像の 2 值化を行い、 通常の画像处理により芯合わせサーボを試みた。これらの プログラムは、パソコン上の Turbo Pascal を使って作成 した。

\section{1 自動芯合わせプログラム}

まず、P L M 1 とPML 2 を、通常の光学的な測定でな るへく平行に、かつ芯が合っているように移動ステージに 取り付ける。この方法で、レンスの平行度は良好に取り付 けられるが、芯合わせ精度は百 $\mu m$ 程度が限界である。 $\mathrm{z}$ ステージを動かして、レンズを焦点距離の 2 倍離し、次の 画像処理プログラムを動作させる。

1. 取り込んだ画像と、 $\mathrm{x}$ または $\mathrm{y}$ 軸を移動して取込んだ 画像を 2 值化し、2つの画像に共通なスポットから点 Aをさがす。

2. 2 值化画像の面積を小さくするように、 $\mathrm{x} 、 \mathrm{y}$ 軸を移 動し、 $\mathrm{x} 、 \mathrm{y}$ 方向を大まかに合わせる。
3. 2. と同じ方法で、 $\theta_{z}$ 方向を大まかに合わせる。

4. 遮光板を捅入し、スポットAの $45^{\circ}$ 方向にある 4 個の スポットの距離がささなるように $\theta_{z}$ を移動し、 $\theta_{z}$ 方 向を正確に合わせる。

5. スポットの $\mathrm{x} 、 \mathrm{y}$. 方向各々の距離を小さくするよう に移動し、正確に合わせる。

この後に接着郕を付け、 $\mathrm{z}$ 方向を移動させ、 2 枚の $\mathrm{P} \mathrm{M}$

\section{しを接着する。}

\section{2 芯合わせ実駼結果}

図 7 か、上述の方法によろ平板マイクロレンスの高精度 芯合わせを行った、評価写真である。 $\mathrm{y}$ 方向と $\theta_{z}$ 方向の誤

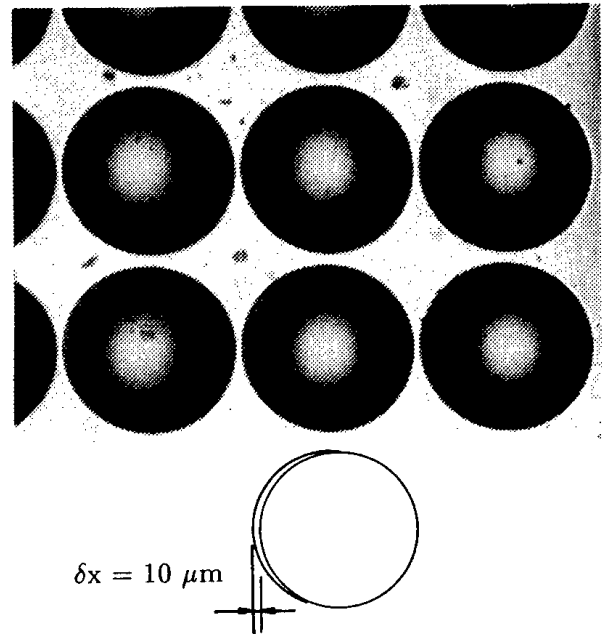

図 7 貼り合わせ結果の評価

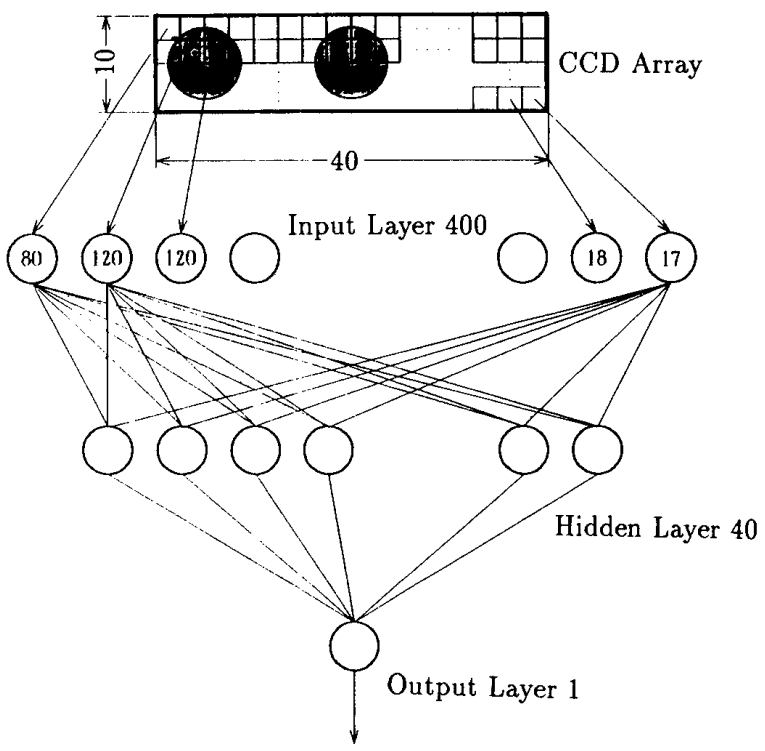

図 8 三層型ニューラルネットワーク 
差は、ほほ买である。しかし、x 方向の諆差は約 $10 \mu \mathrm{m}$ で



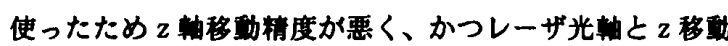
唯には合わせられず、これより少し大きい誤差となっ た。しかし、大量生産の見込みが立ち、PML貼合わせ尃 用の装置を作成すれは、充分精度のよい芯合わせができる ものと確信する。

5 ニューラルネットワークによる自動芯合せの 試み

実用上は、上述の手法で充分な芯合わせができる。しか

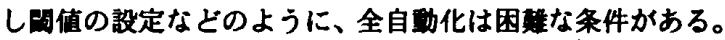
最近、神経細胸を模提したニューラルネットワークの研究が 進み、画像処理に大きな威力を発揮している [4]。本研究の ような、焦点画像よりサーボ信号を作り出す研究は、著者 の知る限り見あたらない。そこで、3届型陼展型ネットワー クのパックプロパゲーション学習則を使い、Many-to-One 画像から芯合わせサーボ信号を作ることを武みた。

\section{1 階屈ネットワークの学署則}

画像テータを入力屏、レンスの芯合わせ諆差を出力首と する、3屈ネットワークの椣成を、図8に示す。各ニュー ロンの入力 $u_{i}^{n}$ およひ出力 $X_{i}^{n}$ は、シグモイド関数を使っ て、次のように表せる。

$$
\begin{gathered}
u_{i}^{n}=\sum W_{j, i}^{n-1, n} X_{j}^{n-1}+h_{i}^{n} \\
X_{i}^{n}=f\left(u_{i}^{n}\right)
\end{gathered}
$$

$$
f(x)=\frac{1}{1+\exp (-x / a)}
$$

このニューロンのダイナミカルモテルを、図9に示す。こ れは、通常の階屏型ニューラルネットワークである。ここ で使った記号は、以下の通りである。

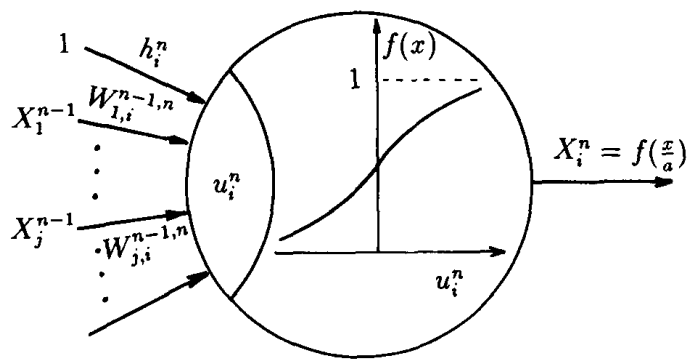

図 9 ニューロンのダイナミカルモテル

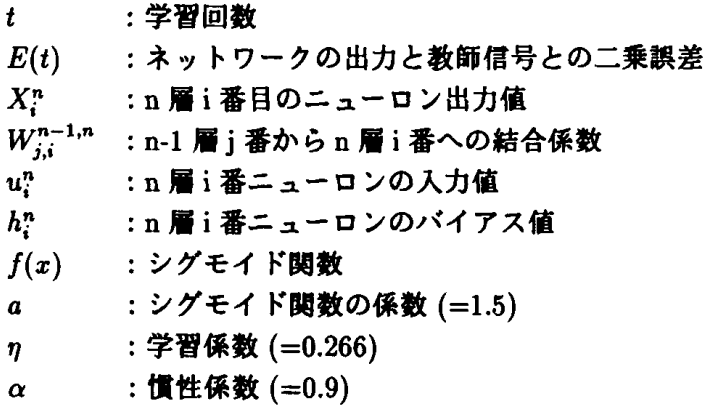

使用したコンピュータの計算速度とメモリの制限から、 今回は $\mathrm{x}$ 方向のみに限定した。したがって、图8の入力展 は、㥞（y方向）に 10 個、横（x方向）に40個のCC $\mathrm{D}$ 泰子、合計 400 個で楼成されている。また、中間首は 40 個、出力屬は 1 個とした。

まず、入力画像と教師信号を取らなければならない。Manyto-One 画像のA点を中央に移场し、B点が左蝶の画像の教 師信号を0、中央（掫も芯汃合っている状㥿）を 0.5 、右 端を1とし、これを含めた中間の画像 45 個のテータを収 集し、ネットワークの学漗を行った。学習則は、通常の俱

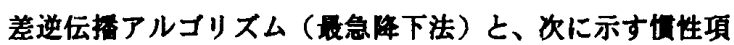
付きの学習則（モーメント法）の双方を試みた [4][5]。

$$
\Delta W_{j, i}^{n-1, n}(t)=-\eta \frac{\partial E(t)}{\partial W_{i j}^{n-1, n}(t)}+\alpha \Delta W_{j, i}^{n-1, n}(t-1)
$$

ここで、クは、学署の速さを決める保数で、大きすきる

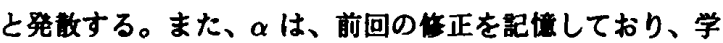
習の振動を抑え、ローカルミニマムに落ち込むことを防ぐ 坆性保数である。これらは、正の実数でなければならない。 $\alpha=0$ のとき、従来の諆差逆伝播法（樶急降下法）となる。

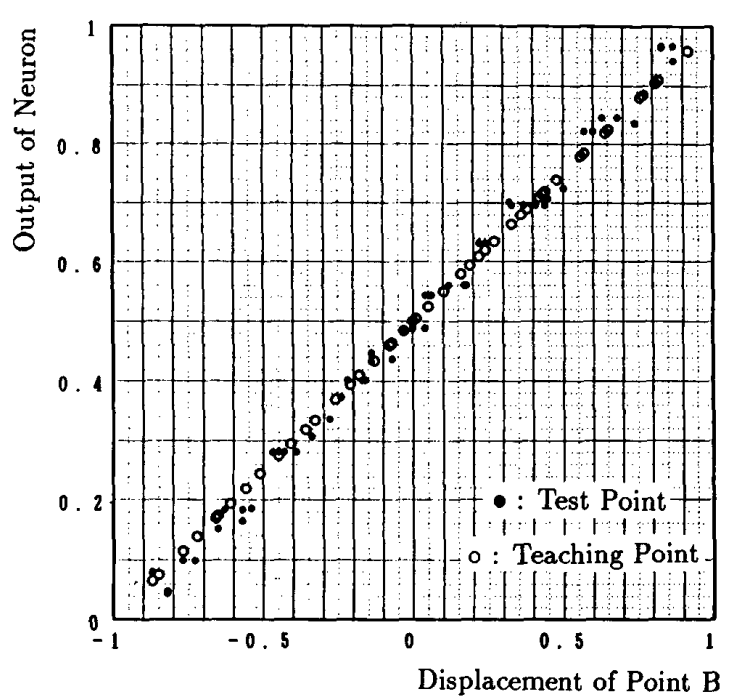

図 100 完成したネットワークの試瞼結果 


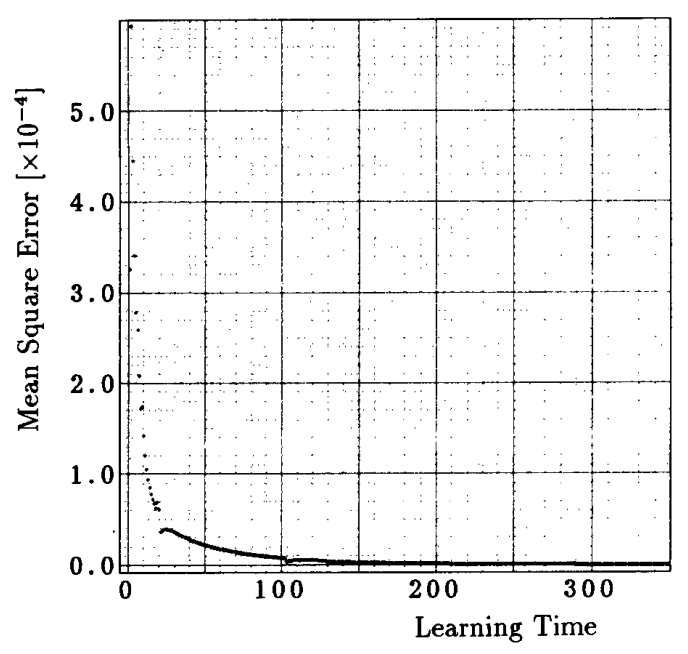

図 11 ネットワークの䛊差の収束

\section{2 学署の結果}

㙋性項付き学習則の結果、図 10 に示すように、スポッ トBの位圈と比例する良好な出力が得られた。ここで。は 数印点を、・はそれ以外の試䁌点を表す。䋛はネットワー クの出力で、横签は図6のC C D 画像から目测で判ったス ポットの横位置である。图 11 には、自乗平均誤差の収束 の様子を示す。横軸は学習回数で、45個の学習点を全て 学署し終わろのを、学習回数 1 回とした。350回の学習 で、完全に収束している。

これに対して通常の俱差逆伝掩学習則ては、うまく行 かなかった。学習の条件をいろいろ変えても、スポットB の位置と出力值にはどこかにうねりが現れ、いくら学署を 綠り返しても比例した出力は得られなかった。この理由は、 ローカルミニマムに陷ったのではないかと考えられる。瑻 性項付き学習則で、割合简単に図 10 のような結果が得 られ、この目的に高い这応能力を示した。

この計算は、80386 \& 387 を使ったパソコンて、Turbo Pascal でプログラムし、学習に約一日かかる。メモリの関 係もあり、 $\mathrm{x}$ 方向しかテストしなかったか、より高速なコ ンピュータを使えは、 $x, y, \theta_{z}$ 三方向の俱差を同時に検出で きるプログラムが作れるものと考えられる。

\section{6 結論}

平板マイクロレンスの製法、応用例を紹介すると共に、 2 枚のレンズの芯合わせを試みた。これをパーソナルコン ピュータの画像処理で、2 種類の芯合せを試み、次の結詥 を得た。

1. 2 收のPMLの芯合わせに、Many-to-One 光学系 (光 ニューロン) が有効であることがわかった。

2. Many-to-One 画像の 2 值化による画像処理は、レン スの芯合せ俱差を简単に検出でき、 $x, y, \theta_{z}$ 三方向の 同時芯合わせに成功した。しかし、閏値の設定など、 全自動化の困轻な問題がある。

3. Many-to-One 画像を入力とする階層型ニューラルネッ トワークに、慣性項付きの誤差逆伝播アルコリスム （モーメント法）を道用し、芯合わせのための楞差伊 号を作ることを陚みた。その結果、少なくとも $\mathrm{x}$ 万向 には良好な結果を得た。

本研究の遂行には、茨城大学近藤良助教投の貫重な助言 があったことを付記し、感草申し上げます。

\section{参考文献}

[1] 谷田貝僼彦 他 4：光コンピューター, サイエンス社, (1989), p25

[2] 及川正舟, 他, Jpn. J. Appl. Opt. 20(1), L51 (1981), \& 20(4), L296 (1981),p1

[3] K. Hamanaka et. al., Applied Optics, Vol. 29, No. 28, (1990), p4064

[4] 麻生英檄, ニューラルネットワーク晴辄処理理詥, 産業 図書 (1989),p1

[5] 浅川和雄, 他 5, 階層ニューラルネットワークの機能と 学習の高速化, SICE 而期セミナー’91 資料, p21 